\title{
INFLUENCE OF PLANT DENSITY ON YIELD OF HYBRID MAIZE (Zea mays L.) UNDER SUPPLEMENTARY IRRIGATION
}

\author{
M.A.P.W.K.Malaviarachchi ${ }^{1}$, K.M.Karunarathne ${ }^{1}$ and S.N.Jayawardane ${ }^{2}$
}

\begin{abstract}
Maize is an important cereal crop grown in Sri Lanka. Hybrid varieties are popular among farmers and the extent cultivated with hybrids has increased over the last few years. Department of Agriculture released the first local hybrid maize variety (Sampath) in 2004. Agronomic practices recommended for open pollinated varieties are not appropriate for highly input responsive hybrids. Therefore, a study was undertaken at Field Crops Research and Development Institute, Mahailluppallama for two consecutive seasons to determine a suitable plant density for hybrid maize. Four densities namely, 55555 (present recommendation), 74074, 88888 and 111111 plants/ha were tested with two varieties (Pacific 984 and Sampath) at $200 \mathrm{~kg} \mathrm{ha}^{-1} \mathrm{~N}$, $100 \mathrm{~kg} \mathrm{ha}^{-1} \mathrm{P}_{2} \mathrm{O}_{5}$ and $50 \mathrm{~kg} \mathrm{ha}{ }^{-1} \mathrm{~K}_{2} \mathrm{O}$. Grain yield increases observed in maha 2004/05 for 74074, 88888 and 111111 plants/ha were $88 \mathrm{kgha}^{-1}$ (2\%), $1114 \mathrm{kgha}^{-1}$ (21\%) and $1708 \mathrm{kgha}^{-1}$ (30\%) respectively and $247 \mathrm{kgha}^{-1}$ (4\%), $1434 \mathrm{kgha}^{-1}$ (24\%) and $1958 \mathrm{kgha}^{-1}$ (33\%) in yala 2005. Two varieties gave the same yields and variations in leaf area, plant height, ear length and 100 seed weight were found not significantly different. Seed number per ear was reduced by $10-16 \%$ at higher densities. Economic analysis revealed that profitability increased by Rs.7000.0011,000.00/ha both at 88888 and 111111 plants/ha densities.
\end{abstract}

Key words: Hybrids, Plant density, Profitability

\section{INTRODUCTION}

Maize is the second most important cereal crop grown in Sri Lanka. It is widely used in both the food and feed industries and consumed as green cobs as well. Total extent of maize cultivated in year 2004 maha was 31500ha and 3300ha in yala (AgStat, 2004). The overall productivity of maize has not been adequate to meet the increasing local demand and consequently maize imports have been increasing over the last several years. However, there are opportunities to increase local maize production in order to save the foreign exchange. Genetic improvement and the expansion of the cultivated area with suitable management practices are two main ways of reaching higher production levels. Currently,
Department of Agriculture has recommended four open pollinated maize varieties (OPV) and the first hybrid maize variety was released in Sri Lanka recently by the Department of Agriculture.

In the recent years, exotic hybrid varieties have become popular among farmers due to their high yield potential. Uniform growth, ability to provide few extra grains per each ear harvested and high plant vigor due to increased metabolic activities are the attributes to this growing interest in hybrid maize among farmers in Sri Lanka (Karunarathna, 2001). The local hybrid variety, 'Samapath' had a yield potential of $9 \mathrm{t} / \mathrm{ha}$ under current management conditions adopted for open pollinated varieties (Karunarathna, 2002). The same 
management package has been recommended for all these varieties though they differed widely in growth duration, growth habits etc. Plant density per unit area is one of the important yield determinants of crops. Hybrid varieties are known to be highly input responsive and the management practices used for open pollinated varieties may not be appropriate to exploit the hybrid vigour of F1 generation. With reference to rice, Jayawardena and Abeysekara (2002), after observing significant variations in yield across different locations concluded that spacing recommended for inbred varieties should be altered for hybrids. Yan (1988) reported that growth characteristics and nutrient requirements of hybrids in any crop are different from the inbred varieties. With reference to hybrid rice Yan (1988) observed that the agronomic management of hybrid varieties differed considerably from that of inbred varieties. An optimum plant population for maximum economic yield exists for all crop species and varies with cultivar and environment (Bruns and Abbas, 2005). The number of plants per unit area of land depends on the variety, its maturity, the productivity of the soil and the water supply. Hybrids have demanded further increases in plant populations for the most profitable returns (Berger,1962). Long (1995) reported that though the generally adopted planting density for maize in China is 50000 plants/ha, the optimal population could be increased up to 75,000 plants/ha due to plant type improvement and increased fertilizer application under favorable irrigated conditions. Plant density is an efficient management tool for maximizing grain yield by increasing the capture of solar radiation within the canopy (Monnveux et al, 2005). Improved hybrids growing at increased plant densities at high fertility levels and with irrigation have greatly increased corn yield in USA (Jugenheimer, 1985). The hybrids have been bred with increased grain yield and yield stability as their primary goals (Duvick and Cassman, 1999). These hybrids often withstand stresses better than earlier cultivars due to some characters like erect leaves and are grown at higher plant population densities to increase the interceptions of solar radiation (Tollenaar, 1991).

Almost all the agronomic studies conducted for maize in Sri Lanka are related to the open pollinated varieties (OPV) (Kathiragamathaiyah and Dharmarajah,1970; Hindagala et.al.,1971; $\quad$ Nagarajah, 1970 ; Nagarajah,1973). There is a scarcity of information available on agronomic management of hybrid maize under Sri Lankan conditions. Hence, a study was conducted to identify an optimum plant density level with an economic analysis for hybrid maize varieties under Sri Lankan conditions.

\section{MATERIALS AND METHODS}

The experiment was conducted at Field Crops Research and Development Institute, Mahailluppallma, in the Low Country Dry Zone (DL1) agro climatic zone during maha 2004/05 and was repeated in yala 2005 on a well drained sandy clay loamy soil. The experiment was carried out as a factorial Randomized Complete Block Design with two hybrid maize varieties (Pacific 984 and Sampath) and four plant density levels with 3 replications. Plant densities tested were 55555 plants $\mathrm{ha}^{-1}$ at the spacing of $60 \mathrm{~cm} \mathrm{X}$ $30 \mathrm{~cm}$ (D1) which is the current recommendation for OPV varieties, 74074 plants $\mathrm{ha}^{-1}$ at the spacing of $45 \times 30 \mathrm{~cm}$ (D2), 88888 plants ha $^{-1}$ at the 
spacing of $75 \mathrm{~cm} X 15 \mathrm{~cm}$ (D3) and 111111 plants $\mathrm{ha}^{-1}$ at the spacing of $60 X 15 \mathrm{~cm}$ (D4). The plot size was 4.2 $\mathrm{m} \times 3.6 \mathrm{~m}$. The crop received $100 \mathrm{~kg}$ $\mathrm{ha}^{-1} \mathrm{P}_{2} \mathrm{O}_{5}$ and $50 \mathrm{~kg} \mathrm{ha}^{-1} \mathrm{~K}_{2} \mathrm{O}$ in the basal dressing and the total amount of nitrogen was applied in two splits at planting $\left(65 \mathrm{~kg} \mathrm{ha}^{-1}\right)$ and 4 weeks after planting (135 kg ha $\left.{ }^{-1}\right)$. Weeds were controlled manually and the stem borer was controlled by application of
Carborfuran at 4 WAS. The crop grown under supplementary irrigation was irrigated once in two weeks during the first 3 months of the crop in maha 2004/05 season where monthly rainfall was above $150 \mathrm{~mm}$ while an irrigation interval of 5 days was maintained during first 3 months of the crop in yala 2005 season where the monthly average rainfall was below $100 \mathrm{~mm}$ (Figure 01).

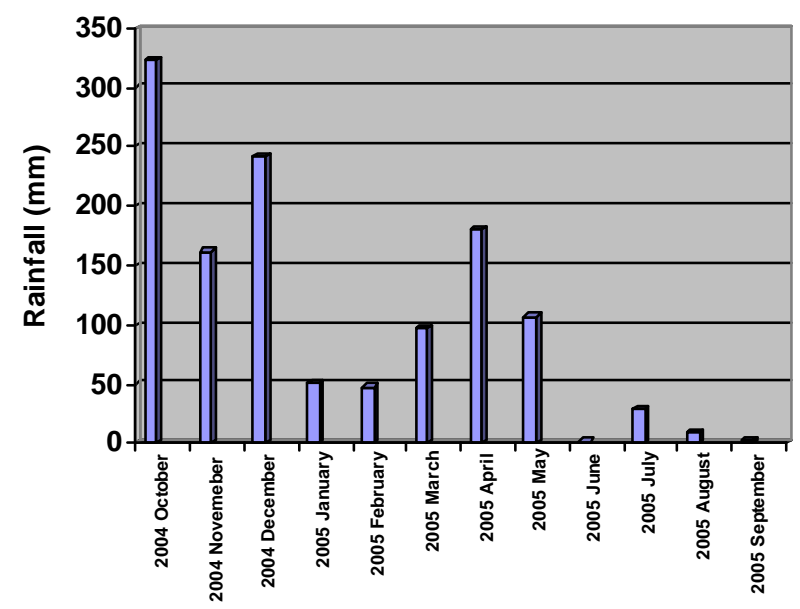

Figure 01: Average monthly rainfall during 2004/05 maha and 2005 yala

Yield components were measured using the net plot area while a sample of 10 randomly selected plants from each plot was taken to measure the plant height and leaf area. The leaf area was estimated using the leaf product method viz. length $\mathrm{X}$ maximum width $\mathrm{X}$ 0.75, as proposed by Montgomery, (1911). All data were analyzed using SAS statistical software and a cost-benefit analysis was also done.

\section{RESULTS AND DISCUSSION}

Average number of cobs per plant was not significantly different at each density level in maha 2004/05 whereas in yala 2005 season, it was observed only a $10 \%$ reduction at 111111 plants/ha population level (Table 01). This indicates that there is no increase in number of barren plants with increasing plant density as in the case of old hybrid varieties developed before 1970 which responded to super optimal plant populations with increase in barren plants (Daynard and Muldoon, 1983).

The interaction effect between variety and plant density for grain yield, seed number per cob, 100 seed weight, leaf area and plant height were not significant. This indicates that the response of two tested hybrid maize varieties to varying plant densities was similar. 
Table 01: Number of cobs per plant

\begin{tabular}{llll}
\hline Density & Yala 2004 & Maha 2004/05 & Yala 2005 \\
\hline 55555 & 0.932 & 0.976 & 0.971 \\
74074 & - & 0.922 & 0.973 \\
88888 & 0.948 & 0.927 & 0.963 \\
111111 & - & 0.927 & 0.884 \\
LSD & ns & ns & 0.062 \\
CV \% & 7.2 & 6.0 & 3.7 \\
\hline
\end{tabular}

Table 02: Yield parameters at different densities in maha 2004/05 and yala 2005

\begin{tabular}{|c|c|c|c|c|c|c|c|c|}
\hline \multirow{2}{*}{$\begin{array}{l}\text { Plant } \\
\text { density } \mathrm{ha}^{-1}\end{array}$} & \multicolumn{4}{|c|}{ Maha 2004/05 } & \multicolumn{4}{|c|}{ Yala 2005} \\
\hline & $\begin{array}{l}\text { Grain } \\
\text { yield } \\
(\mathrm{kg} / \mathrm{ha})\end{array}$ & $\begin{array}{l}100 \\
\text { seed } \\
\text { weight } \\
\text { (g) }\end{array}$ & $\begin{array}{l}\text { Seed } \\
\text { number/ } \\
\text { cob }\end{array}$ & $\begin{array}{l}\text { Ear } \\
\text { length } \\
\text { (cm) }\end{array}$ & $\begin{array}{l}\text { Grain } \\
\text { yield } \\
(\mathrm{kg} / \mathrm{ha})\end{array}$ & $\begin{array}{l}100 \\
\text { seed } \\
\text { weight } \\
\text { (g) }\end{array}$ & $\begin{array}{l}\text { Seed } \\
\text { number/ } \\
\text { cob }\end{array}$ & $\begin{array}{l}\text { Ear } \\
\text { length } \\
\text { (cm) }\end{array}$ \\
\hline 55555 & 5717 & 21 & 514 & 16.3 & 6002 & 29 & 585 & 13.9 \\
\hline 74074 & 5805 & 22 & 462 & 15.2 & 6249 & 28 & 509 & 14.6 \\
\hline 88888 & 6901 & 23 & 446 & 15.2 & 7436 & 28 & 492 & 16.4 \\
\hline 111111 & 7425 & 21 & 434 & 14.5 & 7960 & 28 & 501 & 17.3 \\
\hline LSD(5\%) & 1127 & ns & 67 & ns & 2699 & ns & 72 & ns \\
\hline Sampath & 6274 & 23 & 449 & 15 & 7489 & 30 & 570 & 15.9 \\
\hline $\begin{array}{l}\text { Pacific } \\
984\end{array}$ & 6650 & 24 & 479 & 15 & 7553 & 27 & 559 & 16.4 \\
\hline $\begin{array}{l}\text { LSD } \\
(5 \%)\end{array}$ & ns & ns & ns & ns & ns & ns & ns & ns \\
\hline $\mathrm{CV} \%$ & 14.09 & 9.24 & 7.32 & 7.63 & 20.67 & 14.32 & 11.38 & 10.38 \\
\hline
\end{tabular}

Table 03: Leaf area and plant height at different densities

\begin{tabular}{lllll}
\hline $\begin{array}{l}\text { Plant } \\
\text { density ha }\end{array}$ & \multicolumn{3}{c}{ Maha 2004/05 } & \multicolumn{2}{c}{ Yala 2005 } \\
\cline { 2 - 5 } & $\begin{array}{l}\text { Leaf } \\
\text { area/plant } \\
\left(\mathrm{cm}^{2}\right)\end{array}$ & $\begin{array}{l}\text { Plant height } \\
(\mathrm{cm})\end{array}$ & $\begin{array}{l}\text { Leaf } \\
\text { area/plant } \\
\left(\mathrm{cm}^{2}\right)\end{array}$ & $\begin{array}{l}\text { Plant height } \\
(\mathrm{cm})\end{array}$ \\
\hline 55555 & 7118 & 241 & 7889 & 225 \\
74074 & 6780 & 240 & 6995 & 230 \\
88888 & 7046 & 235 & 7778 & 229 \\
111111 & 7185 & 249 & 7500 & 234 \\
LSD(5\%) & $\mathrm{ns}$ & $\mathrm{ns}$ & $\mathrm{ns}$ & $\mathrm{ns}$ \\
Variety & & & & \\
Sampath & 7100 & 234 & 7903 & 227 \\
Pacific & 7204 & 251 & 8005 & 233 \\
LSD(5\%) & $\mathrm{ns}$ & 9 & $\mathrm{~ns}$ & $\mathrm{~ns}$ \\
CV \% & 12.5 & 13.2 & 10.3 & 9.8 \\
\hline (n =10) & & & &
\end{tabular}


Experiment conducted in maha 2004/05 season showed an increase in grain yield with increasing plant population density. When compared to the recommended level (55555 plants $\mathrm{ha}^{-1}$ ), a $21 \%$ and $30 \%$ yield increases were recorded under 88888 plants ha $^{-1}$ and 11111 plants $\mathrm{ha}^{-1}$ respectively (Table 02). The seed number/cob decreased by $10 \%-16 \%$ compared to 55555 density. Though seed number decreased with increasing plant density, it was not statistically significant above 74074 plants ha ${ }^{1}$ density level.

A yield increase of $247 \mathrm{~kg} \mathrm{ha}^{-1}(4 \%)$, $1434 \mathrm{~kg} \mathrm{ha}^{-1}(24 \%)$, and $1958 \mathrm{~kg} \mathrm{ha}^{-1}$ (33\%) was observed at 74074, 88888 and 111111 densities respectively in yala 2005 when compared to the recommended level. A decreasing trend in seed number per cob was observed in the second season too which was around $15 \%$ at higher densities compared to 55555 (Table 02). This was confirmed by Dien, (1997) observing negative correlations between yield components and densities except for the total grain yield.

No variations in 100 seed weight and ear length were observed in both seasons. Lower yields in both seasons with respect to 74074 density could be due to the low light distribution among leaves due to relatively low inter row spacing $(45 \mathrm{~cm})$. No yield differences were observed between local and foreign hybrids.

There was a steady increase in the LAI with plant density in every season because there were no significant variations in leaf area per plant (Table 03 and Fig 02). Krishnamuthy et al (1973) also observed a similar pattern. Light availability has a great influence on the leaf area and the plant height of any crop. If the light penetration into the canopy is low, plants tend to grow taller and to have lower leaf areas. The data showed that there were no significant differences observed in leaf area and plant height with the different density levels indicating no significant differences in light availability within the canopy at each density levels (Table 03). There was no variation in leaf area between two varieties whereas plant height was higher in Pacific in maha season but same in yala season. The reason behind this may be the low radiation availability in maha compared to yala due to the cloudiness experienced in maha.

A similar pattern of yield variation was observed in both seasons with increasing plant population density of maize (Figure 3a and 3b). Since 100 seed weight and growth parameters like leaf area, plant height did not vary significantly and seed number per cob decreased, it could be concluded that the only factor contributing to yield increase is the number of cobs per unit area which is equal to number of plants per unit area since average number of cobs per plant is approximately one (Table 01). This conclusion is in agreement with Dien (1997) who reported that overall grain yield of maize increased due to increasing number of cobs per hectare due to higher plant density.

Even though the ear length was not significantly changed among the densities tested, reduction in seed number per cob indicates that the size of the cob is getting smaller. Some authors (Hlaning, 1996; Dien, 1997) have observed a reduction in kernel rows and cob diameter at high plant densities but an increase in grain yield. Berger (1962) concluded that planting too closely would result in smaller cobs but large cobs are secured only by 
sacrificing a considerable yield. Thus, it is possible to go for higher densities when maize is grown for grains but for green cobs high density can not be applied.

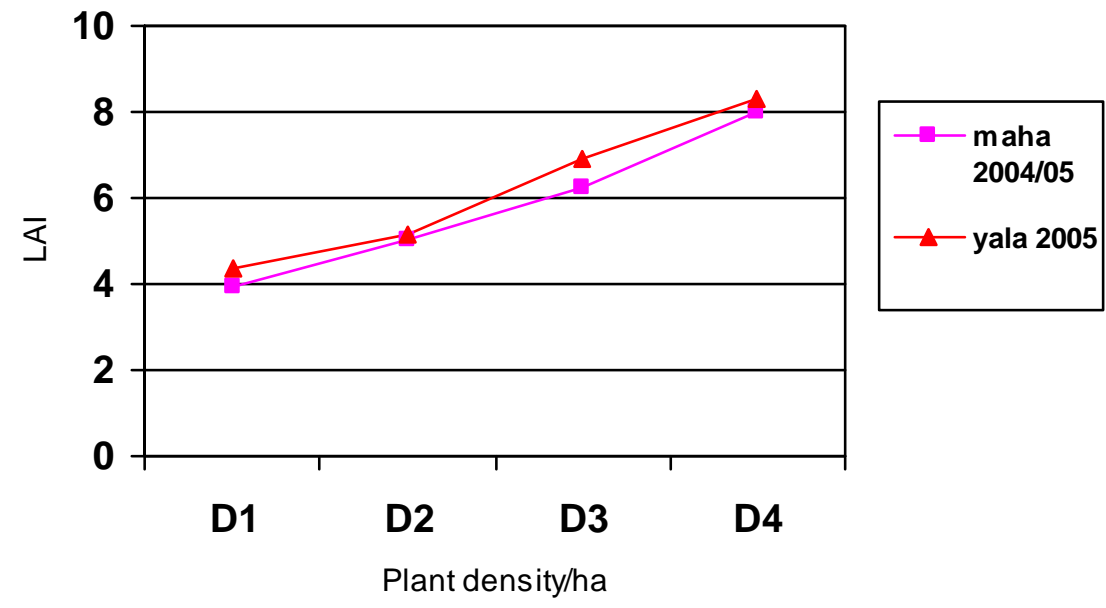

Figure 02: Change in leaf area index with increasing plant density in different seasons

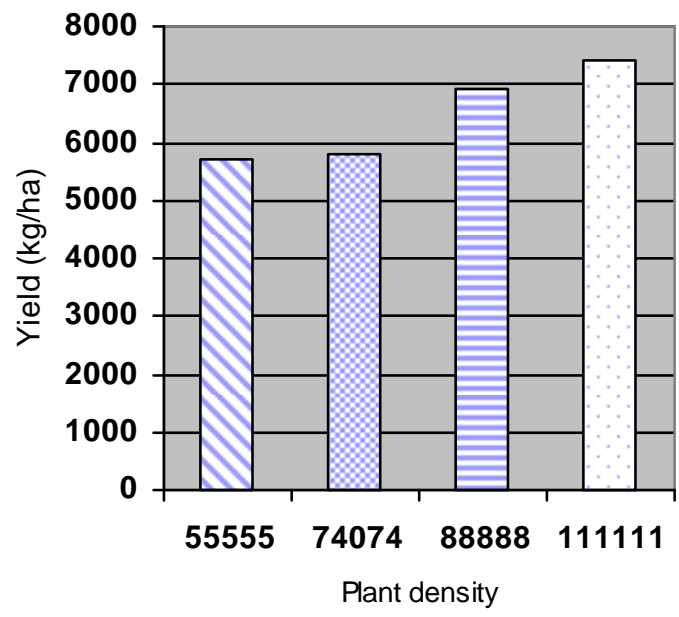

$$
\mathrm{n}=50
$$

Figure 03a: Yield variations at different densities in maha 2004/05 season

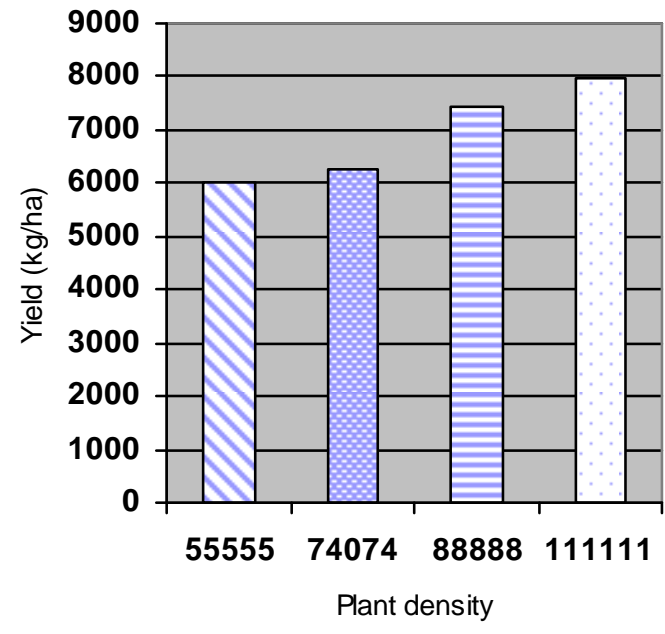

$$
\mathrm{n}=50
$$

Figure 03b: Yield variations at different densities in yala 2005 season 
Table 04: Cost of cultivation of maize at each density

\begin{tabular}{lllllll}
\hline Management practice & \multicolumn{3}{c}{ Total labor cost(Rs.) } & \multicolumn{4}{c}{${ }^{1}$ Total cost (Rs./ha) } \\
& \multicolumn{3}{c}{ densities (plants/ha) } & \\
\cline { 2 - 7 } & ${ }^{2} 55555$ & 88888 & 111111 & ${ }^{2} 55555$ & 88888 & 111111 \\
\hline Land preparation & 4668 & 4668 & 4668 & 9754 & 9754 & 9754 \\
Seeding & 4010 & 6416 & 8020 & 7174 & 11479 & 14349 \\
Fertilizer application & 2815 & 2815 & 2815 & 7946 & 11065 & 11065 \\
Weeding and & 5890 & 5890 & 5890 & 5890 & 5890 & 5890 \\
earthing up & & & & & & \\
Irrigation & 1200 & 1200 & 1200 & 2250 & 2250 & 2250 \\
Harvesting & 4806 & 7690 & 9612 & 4806 & 7690 & 9612 \\
Threshing & 1689 & 2703 & 3378 & 2456 & 2703 & 4913 \\
Transport to stores & 0 & 0 & 0 & 772 & 1236 & 1545 \\
3Total cost & 25078 & 31382 & 35583 & 41048 & 52067 & 59378 \\
\hline
\end{tabular}

Table 05: Partial budget for maize under different density levels

\begin{tabular}{|c|c|c|c|c|c|c|}
\hline Season & \multicolumn{3}{|c|}{ Maha 2004/05 } & \multicolumn{3}{|c|}{ Yala 2005} \\
\hline $\begin{array}{l}\text { Population density } \\
\text { (plants/ ha) }\end{array}$ & ${ }^{2} 55555$ & 88888 & 111111 & ${ }^{2} 55555$ & 88888 & 111111 \\
\hline Yield (kg/ha) & 5717 & 6901 & 7425 & 6002 & 7436 & 7960 \\
\hline Gross income (Rs/ha) & 85755 & 103515 & 111375 & 90030 & 111540 & 119400 \\
\hline Total cost (Rs/ha) & 41048 & 52067 & 58328 & 41048 & 52067 & 59378 \\
\hline Net income (Rs/ha) & 44707 & 51448 & 53047 & 48982 & 59473 & 60022 \\
\hline $\begin{array}{l}{ }^{3} \text { Profit increase over } \\
\text { current practice } \\
\text { (Rs./ha) }\end{array}$ & - & 6741 & 7290 & - & 10491 & 11040 \\
\hline
\end{tabular}

\section{Economic analysis}

Labour component of cost of cultivation for seeding, harvesting and threshing increased with increase in plant population density while it remains same for other cultural practices. For the cost benefit analysis, the partial budget technique was followed (CIMMYT, 1988) and it was assumed that the labour requirement increased proportionately when the plant density is increased; i.e. 1.6 times for 88888 and 2 times for 111111. Cost of cultivation under present management package is
Rs.38798.00/ha (Department of Agriculture, 2004). Accordingly, cost increase for 88888 and 111111 densities are $28 \%$ and $49 \%$ (Table 4 ). Income was calculated at Rs.15.00/kg which is the average market price for maize seeds during 2003/04 maha season (Department of Agriculture, 2004). Thus farmers' profit increase in both seasons is more or less similar for both 88888 and 111111 compared to present recommendation and it was Rs. 6741.00 and Rs. 7290.00 in maha 2004/05 and 10491.00 and 11040.00 in yala 2005 respectively (Table 5). 


\section{CONCLUSION}

It is economical to increase plant density up to 88888 plants ha $^{-1}$ when hybrid maize is grown for grains where profit is increased by Rs. 6700.0010500.00 at $200 \mathrm{~kg} /$ ha Nitrogen, $100 \mathrm{~kg}$ ha $^{-1} \mathrm{P}_{2} \mathrm{O}_{5}$ and $50 \mathrm{~kg} \mathrm{ha}^{-1} \mathrm{~K}_{2} \mathrm{O}$ level. This density can not be applied for maize grown for green cobs.

\section{References}

AgStat, (2005). Pocket book of agricultural statistics. Socio-economic planning centre, Department of Agriculture, Peradeniya, Sri Lanka

Berger, J. (1962). Maize production and manuring of maize. Conzett, Huber and Zuruch, Switzerland. pp. 48-50

CIMMYT. (1988). From Agronomy Data to Farmer Recommendation. An Economic Training Manual. Completely revised edition. Mexico. D.F. pp. 20-29

Bruns, H.A.and H.K.Abbas. (2005). Ultra-High plant populations and nitrogen fertility effects on corn in the Mississippi Valley. Agronomy Journal. Vol. 97. No.4. p. 1136.

Department of Agriculture. (2004). Cost of production. Maha 2003/2004. Department of Agriculture, Peradeniya, Sri Lanka.

Dien, D.H. (1997). The performance of Hybrid KSX 3853 under different planting density and fertilizer level. In Seed production of maize in Asia and research in crop management. Nakhonratehasima, Thailand. pp. 167-169.

Daynard,T.B. and J.F. Muldoon. (1983). Plant to plant variability of maize plants grown at different densities. Canadian Journal of Plant Science. 63. pp. 45-59

Duvick, D.N. and K.G. Cassman (1999). Post-green revolution trends in yield potential of temperate maize in the North Central United States. Crop Science. 39. pp. $1622-1630$

Hindagala, C.B., S. Kandasamy and S. Nagarajah (1971). Response of maize (Zea mays) to fertilizers at Bibile and Mahailluppallama. Tropical Agriculturist. Vol. CXXVII. pp. 197-198

Hlaning,U.T.(1996). Effect of plant density and duration of weed competition on yield of maize. In training report of Asia maize centre, Nakhonratchasima, Thailand. pp. 88-89.

Jayawardena, S.N. and S.W.Abeysekara (2002). Effect of plant spacing on the yield of hybrid rice. Annals of Sri Lanka Department of Agriculture. Vol. 4. pp. 1520

Jugenheimer, R.W. (1985). Maximum corn production depends on many factors In Corn improvement, seed production and uses.. Kreiger. E.R. pp. 11-18

Krishnamurthy,K.A.Bommegowda,B.G.Rajasekara,M.K.Jagannath,T.V.Ramachanra, G.Raghunatha,N.Venngopal and G.Jayaram. (1973). Agronomy department. University of Agriculture Sciences, Bangalore, 560-024, India. pp. 48-95

Karunarathne, K.M (2002). Annual research report, Field crops research and development institute, Department of Agriculture, Sri Lanka (unpublished)

Karunarathne, K.M. (2001). Variety development and productivity enhancement of hybrid maize in Sri Lanka. Annals of Sri Lanka Department of Agriculture. Vol. 3. p. 85

Kathirgamathaiyah, S. And N. Dharmarajah, (1970). Fertilizer experiments with maize (Zea mays) on a Bibile soil. Tropical Agriculturist. CXXVI pp. 91-94

Long, Z. C. (1995). Hybrid maize in China. A success story. RAPA Eds by N.Chomchalow and H.V. Henke publications, Bangkok, Thailand. p. 16 
Monneveux, P., P.H. Zaidi and C. Sanchez (2005). Population density and low nitrogen affects yield. - Associated Traits in Tropical Maize. Crop Science. Vol. 45(2)

Montgomery, E.G. (1911). Correlation studies in maize. Nebrasaka Agr.Exp.Sta.Rep. 24: $108-159$

Nagarajah, S, C.B. Hindagala and P.Periyasamy (1973). Nitrogen and Phosphorus fertilizer for maize production. Tropical Agriculturist. Vol CXXIX. pp. 27-29

Nagarajah, S. (1970). Fertilization of subsidiary food crops and minor export crops. Journal of Soil Science Society Ceylon I. pp. 146-153

Tollenaar,M. (1991). Physiological basis of genetic improvement of maize hybrids grown in Ontario from 1959 to1988. Crop Science. 31. pp. 119-124

Yan, Z.D. (1988). Agronomic management of rice hybrids compared with conventional varieties. In Hybrid rice. International rice research institute, Manila. pp. 217-223 